\title{
Perception of Target Household Members on Hope Family Program in Dradahblumbang Village Lamongan District of Indonesia
}

\author{
Nashihin $^{1}$, I Made Weni ${ }^{2}$, Tommy Hariyanto ${ }^{3}$ \\ ${ }^{1-3}$ University of Merdeka Malang \\ Indonesia
}

\begin{abstract}
Factually, the household poverty rate tied to health and education. Low and weak household income below the poverty line causes such households are unable to meet the needs of especially the health and education needs. This study aimed to describe and analyze the perceptions of members of the target households in the village hope the family program Dradahblumbang subdistrict in Lamongan district Kedungpring and to describe and analyze the factors that affect the internal and external perception of members of targeted household member against family program expectations in the village Dradahblumbang Kedungpring subdistrict in Lamongan district. Data were analyzed by three steps, ie condensation of data, a data display, and conclusion drawing or verification. The analysis shows that Member targeted households desperately need their family program this expectation, they are well aware that with this program hope their families will receive cash assistance to alleviate the needs of family life, particularly for school fees and for other purposes. Targeted household members' opinions on the implementation of validation and updating data is generally "good", they were also very responsive, just that there are some family program participants hope that submitted the validation and updating it to the head of the group, family program companion even hope itself sometimes tell the group leader to validate and update the data members. Understanding of targeted household members on the benefits of family programs hope is "good", although there are some family program participants hope that still need intense intervention or approach. This happens because some of the participants of the family hope to use the family program funding expectations for personal use, but after a surveillance approach and gradually change for the better.
\end{abstract}

Keywords: Perception, Household Target, Family Hope Program.

\section{INTRODUCTION}

Target Households (RTS) is households fall in the category of very poor, poor and near-poor (Instruction No. 3 of 2008 on the Implementation of the Direct Cash Assistance Program for Domestic Goals). To support the implementation of the program of the family hope then formed institutional family hope program that consists of a steering committee center (UPPKH Center), Unit program managers of the family hope provinces (UPPKH Province), Unit program managers of the family hope the district / city (UPPKH district / city) is equipped with family program management information system include computer-based expectations are also carriers of information technology (IT) with expertise in program management information system of the family hope (SIM-PKH) Program implementation unit of the family hope subdistricts (UPPKH sub-district) composed of counselors recruited from the community, youth, scholars engine of development, and elements of civil society organizations. In general, PKH escort duty to accompany extremely poor households (RTSM) PKH participants in the use of accessibility to education and health services.

On social assistance programs that have been run by the government are factors and the impact of the implementation of the program. It also occurs in CCT program. For example, research conducted by Hermawati, et al., On the implementation of the CCT program in North Sulawesi province in the city of Bitung in 2007. From the results of these studies obtained the data related to the supporting factors, inhibiting factors, the positive effects and the negative impact of the implementation of the program, Supporting factors such as PKH clear implementation mechanism, a good cooperation between the parties involved, and so forth. While there are still many inhibiting factors such as extremely poor households (RTSM) which have not been recorded by the BPS, health and education facilities are inadequate and so forth. The positive impact for instance an increase in educational services bagianak primary and secondary school age RTSM, improved maternal and child health status RTSM, and so forth. The latter is the negative impact of such diversion of aid by the recipient for purposes other needs besides education and health, arising chances of unscrupulous officials to abuse the favor, and raised social jealousy among the people because there are some RTSM not get help (Hermawati 2008: xvi ). 
According to information from the department of manpower and transmigration Lamongan in coordination meetings companion and operator CCT, in 2007 the program beneficiaries of the family hope as many as 13 districts, and only in 2016 all districts in Lamongan has entered into a recipient family program expectations with participants as many as 23550 SHGs. While in 2017 Lamongan district received help as much as 91 billion to 48172 beneficiary families.

Kedungpring is one of the districts that received family program expectations in 2017 consisting of 23 villages with 3,123 families of beneficiaries. Of these families program participants hope that most of the village Dradahblumbang KPM 325 with the aid of Rp. 770100 000, - per year. (Lasting, village Companion Dradahblumbang)

Based on preliminary information from Lasting, companion PKH Dradahblumbang village subdistrict in Lamongan district Kedungpring, the general implementation of CCT programs running smoothly. However there are concerns among many families have been able to still get in as participants PKH but on the other side of the target households are not included in the membership PKH, aid is used for other purposes besides education and health, arising opportunities for abuse of the participants PKH (Card PKH made loan guarantees on bank loans), and the emergence of social jealousy among targeted households (RTS) because there are some that are not included as participants PKH. In fact, never happened perkelaihan in one family for over money PKH aid.More Lasting said the aid actually not be contested because the money has obvious uses is for the children's education expenses. Another thing that is still often the case that the aid be used outside the education and health needs, they do it with reason.

Based on initial observations in the village Dradahblumbang who made the object of this research turned out to be unique, interesting and specific. 1) Unique to study because the recipient PKH PKH card to be used as collateral in credit unions; 2) interesting to study because in the village there Dradahblumbang 3 companies, namely PT. Industrindo Dewata, PT. Interkraf and PT. Gudang Garam partners Going forward, the logic is the existence of these companies will provide economic benefits to the community as much as possible Dradahblumbang village, but the fact that in 2016 the number of participants by 75 RTS PKH but in 2017 it increased to 325 RTS; 3) Specific for poor people in the farming village Dradahblumbang using forests to agricultural land intercropping by way of rent,

On the other hand, the response members targeted households (RTS) on the benefits of family programs vary expectations include: (1) the more immediate household needs, while education and health can be delayed; (2) because PKH aid from the government so its use is up to the recipient; (3), elsewhere also do the misuse of aid similar to that carried them; (4) abuse of the aid will not be in prison for the leaders even more who abuse state finances. It turned out that their perception is strongly influenced by the ability to receive information about the rights and obligations of participants PKH of a companion, so that the resulting differences in viewpoints. This is in accordance with the opinion of Sugihartono, et al (2007: 8) that perception is the brain's ability to translate the stimulus or process for translating stimulus into the human sensory organs. Human perception standpoint there are differences in sensing. There are perceiving something is good or perception of positive and negative perceptions that affect human action that looks or real.

This study aimed to describe and analyze the perceptions of members of the target households in the village hope the family program Dradahblumbang subdistrict in Lamongan district Kedungpring and to describe and analyze the factors that affect the internal and external perception of members of targeted household member against family program expectations in the village Dradahblumbang Kedungpring subdistrict in Lamongan district.

\section{LITERATURE REVIEW}

\subsection{Concept of Perception}

Many experts made the definition of perception, one of which is Poerwodarminto said the term perception "as an absorbed, received by means of the senses, such as seeing, hearing, tasted or often translated as shadows in imagination, opinion, view, designation or reactions in fact leads to what ditanggapinya through the senses imagined in his dreams "(Poerwodarminto, 1976: 675). Furthermore, according to Ben Walgito states that: "Perception is a process that occurs within the individual that begins with the receipt of rangsa, until the stimulus itself and understood by the people so that people can recognize themselves and the surrounding circumstances" (Walgito, 2004: 70). While Zarkasi describes perception as follows:

\subsection{The concept of Target Households (RTS)}

According to the National Encyclopedia volumes of the 14th, which is the "home" is a residence or building for human habitation. This word melingkup all forms of human habitation from the palace to the cottage simplest. While households have a sense of shelter and its inhabitants, and anything that is inside. Meanwhile, according to Nazar Sidi Bakry (1993: 26) Housekeeping is a collection of the smallest communities consisting of spouses, children, in-laws and so on. As is the target households (RTS) is households fall in the category of very poor, poor and near-poor (Instruction No. 3 of 2008 on the implementation of direct cash assistance program for targeted households). 


\subsection{The concept of the Family Hope Program}

CCT is a social protection program that provides cash assistance to Family Very Poor (KSM) and for the family members of KSM obligated to carry out the terms and conditions determined. In a companion workbook and family program operators hope issued by the Directorate General of Protection and Social Security, Ministry of Social Affairs (2015: 1-10) explained that the Family Hope Program (PKH) is a program of conditional cash assistance to Family Very Poor (KSM) eligible membership and established by the Ministry of Social Affairs.

\section{METHOD}

\subsection{Research approach}

To reveal the phenomenon in society, in this case the perception of members of targeted households (RTS) on the implementation and benefits of family programs expectation $(\mathrm{PKH})$ in the sub-district village Kedungpring Dradahblumbang Lamongan using qualitative research approach. According Moleong (2006: 6) Qualitative research is research that aims to understand the phenomenon of what is experienced by the subjects of research; eg, behavior, perception, motivation, action and others, holistically and by way of description in the form of words and language, in a specific context naturally by using various scientific methods.

\subsection{Research focus}

Focus and indicators in this study was formulated as follows:

1. Members perception Target Households (RTS) to the Family Hope Program, with the following indicators:

a. Views of members of targeted households (RTS) against PKH

b. Opinion of members of targeted households (RTS) on the implementation of PKH

c. Understanding of members of targeted households (RTS) to the benefit of PKH

2. Factors that influence the perception of members of the RTS on the implementation and benefits of family program expectations, with the following indicators:

a. Internal factors that influence the perception of members of targeted households (RTS) on the implementation and benefits of CCT.

b. External factors influencing the perception of members of targeted households (RTS) on the implementation and benefits of $\mathrm{PKH}$

\subsection{Techniques for Data Analysis}

Qualitative data analysis in this research since before plunging into the field, observation, during the conduct of research in the field and after the completion of research in the field. The research data was obtained from interviews, observation and documentation. The data analysis was done by way of organizing data obtained into a category, describe data into units, analyze the data that is important, preparing or presenting the data according to research problem in the form of a report and make conclusions to be easy to understand.

Data were analyzed using the appropriate steps theory Miles, Huberman and Saldana (2014), which analyzed the data by three steps: condensing the data (data condensation), the present data (data display), and draw conclusions or verification (conclusion drawing and verification). Condensation of data referring to the electoral process (selecting), the convergence (focusing), simplification (simplifiying), peringkasan (abstracting), and data transformation (transforming). In more detail, the steps according to the theory Miles, Huberman and Saldana (2014).

\section{DISCUSSION}

\subsection{Members perception Target Households (RTS) Against the Family Hope Program (PKH)}

Perception plays an important role in doing something and influential in the mindset and behavior and to make choices about what to do. Assessment of things is strongly influenced by the perception given to such things. Something that can be positive or negative response is highly dependent on the perception given. As described above perceptions in this research is the view of members of targeted households (RTS) to the program of family expectations, opinion of members of targeted households (RTS) on the implementation of the program family expectations and understanding of members of targeted households (RTS) to the benefits of the program expectations family in the village of the District Dradahblumbang Kedungpring Lamongan.

\subsubsection{Members outlook Target Households (RTS) Against the Family Hope Program (PKH)}

CCT is a social protection program that provides cash assistance to Family Very Poor (KSM) and for the family members of KSM obligated to carry out the terms and conditions determined. Although this requires a CCT program requirement for members of targeted households (RTS) which passes into PKH participants, but all members of the target households (RTS) feel happy and grateful to get in this program. On average they feel happy and grateful for the program entry $\mathrm{PKH}$, PKH program they are entitled to financial assistance in the form of money that can be used to help support themselves and the rights of others. 
Participants PKH have rights, namely: (1) To get the cash assistance as per the requirements, Got health care at health care providers (health centers, Posyandu, Polindes, etc.), (2) Got an education service for children aged compulsory education 9 years old and 15-18 year olds who have not completed primary education, through formal education programs, informal and nonformal, (3) PKH participants enrolled in other social assistance programs (Assurance, BSM, Raskin, Kube, BLSM).

Members of targeted households (RTS) desperately need their family hope program (PKH), they are well aware that with the PKH program they will receive stipends to alleviate the needs of family life, particularly for school fees and for other purposes. Their view is that the CCT program will provide new hope for the future of their children, because they are no longer bothered with school fees. They also have to understand that aid CCT program is not free, but there are requirements that must be met. They also understand if the predetermined requirements are not met then there will be a reduction in aid.

Perception "positive or good" members of targeted households (RTS) to the family program turned out to be very subjective expectations, so that understanding is very individual. In this study, there are some members of the suspected target households (RTS) who say that they meet the requirements because they do not help cut as presented Mrs. NRL (29 th) and Mrs. Cash (45 th). On the other side there that says the commitment to meet those obligations so that children become proficient as presented by Ms. Sri (38 th) and the Capital Sum (58 th).

From some of the information is proved that they are happy with the expectations family program (PKH) because it can help relieve the needs of their family life. This is likely to be a factor that led to the "perception" of their expectations of the family program $(\mathrm{PKH})$.

\subsubsection{Members Opinions Target Households (RTS) on the implementation of the Family Hope Program (PKH)}

a. Validation and Data Updates

Data validation is implemented by the companion PKH to ensure that the candidates are worthy of being participants PKH. This activity is to mencrosceck component data in the family who meet the entry requirements as PKH participants. Furthermore, the data collection process is usually referred to as updating data. Updating the data at any time, but in general carried out after the disbursement process PKH. Updates massive data made after the increase in class at school / madrasah, because at that time many changes in the status of the components, eg initially toddler turns into a SD / MI and so on.

b. Implementation FDS / P2K2

Family Development Session / Upgrades Family meetings are a learning process for participants of the Family Hope Program (PKH) for the provision of practical information and discussion in the field of education, health, economy, child protection and social welfare conducted in group meetings every month.

c. Disbursement of funds PKH

With regard to the data sent by UPPKH regency / city regarding the fulfillment of commitments in health facilities and education facilities, which was sent to UPPKH Center. UPPKH Center to verify the data, having known the exact amount of aid per-KSM then carried through the assistance disbursement PT. Post in each district. In 2017 liquefaction system is done with the cash system, where each RTS received ATM and passbook from Bank BNI 46, and disbursements can be done in joint ATM throughout Indonesia.

The stages of aid flows Family Hope Program are as follows: (1) Assistance is provided to the participants as much as 4 stages PKH year; (2) Especially in the second stage, in addition to assistance based on commitment, PKH participants also get help anyway.

\subsubsection{Members comprehension Target Households (RTS) To Benefit Family Hope Program (PKH)}

Understanding of members of targeted households (RTS) on the benefits of family programs hope is their ability to utilize $\mathrm{PKH}$ aid to be used in accordance with the purpose of providing assistance PKH. In the short term relief PKH help reduce the burden of the family expenses very poor, while in the long run by requiring recipient families to send their children, immunize infants, consult the womb for pregnant women, examination postpartum for postpartum mothers and nutrition, is expected to be able to break the chain of poverty.

The specific objectives of CCT are: (1) improving socio-economic conditions are very poor families; (2) improve the education of children is very poor family; (3) improve the health and nutritional status for pregnant women, postpartum mothers, and children under 6 years of very poor families; (4) improving access to and quality of education and health, especially for very poor families. Understanding of members of targeted households (RTS) on the benefits of family programs expectation (PKH) already shows the categories of "good", although there are some participants PKH still need intense intervention or approach.

From this research it was found on the Part of PKH participants who use assistance for personal use. This habit dilakuakn because they follow other PKH participants and it turned out they were safe. But with the approach and supervision carried out by the customs PKH companion gradually changed towards the better. At least they use CCT funds for the needs of schools and nutritious food for toddlers, if still more will be used for personal needs. 


\subsection{Factors Influencing Perceptions Target Household Member (RTS) of Implementation and Benefits of the Family Hope Program (PKH)}

\subsubsection{Internal factors}

As described in the previous chapter that the internal factors that influence the perception of members of targeted households (RTS) against expectation family program (PKH) are education and motivation. Education is essentially a conscious effort and planned to develop the capacity of self that lasts all human life is not limited by space and time. According to John Dewey, as quoted by Abu Ahmadi (2003: 69), education is the process of establishing the fundamental abilities intellectually and emotionally towards nature and fellow human beings. Meanwhile, according to Ngalim Purwanto (2003: 11) Education is all the effort of adults in association with the kids to lead the physical and spiritual development toward maturity.

\subsubsection{External factors}

External factors that influence the formation of perceptions of members of targeted households (RTS) on the implementation and benefits of the Family Hope Program (PKH) are: the social environment and family background. The social environment is the environment in which we socialize, communicate and interact with individuals and with the community and other groups. According Stroz (1987: 76) the social environment includes "all the conditions in the world in certain ways affect a person's behavior, including growth and development or life process, which can also be seen as preparing the environment (to provide the environment) for the generations other".

\section{CONCLUSION}

\subsubsection{Members perception RTS to the Family Hope Program (PKH)}

In accordance with the purpose of research, some conclusions as follows:

a. RTS members' views to the CCT program

Members of targeted households (RTS) desperately need their family hope program (PKH), they are well aware that with the PKH program they will receive stipends to alleviate the needs of family life, particularly for school fees and for other purposes. Their view is that the CCT program will provide new hope for the future of their children, because they are no longer bothered with school fees. They also have to understand that aid CCT program is not free, but there are requirements that must be met. They also understand if the predetermined requirements are not met then there will be a reduction in aid. Family program expectations $(\mathrm{PKH})$ is in operation has been right on target,

\section{b. RTS members' opinions on the implementation of CCT program}

RTS members' opinions on the implementation of CCT programs can be viewed from three (3) things: validation and updating of data, implementation of the FDS / P2K2 disbursement and implementation of PKH are already performing well. Opinion of members of targeted households (RTS) on the implementation of validation and updating of the data is generally "good", they were also very responsive, just that there are some participants PKH submit the validation and updating it to the head of the group, even companion PKH themselves sometimes tell chairman of the group members validate and update the data. This action is done because many of them do not understand the data validation and updating of these, their concerns if done alone would happen mistakes that result in reduced funding.

The seriousness of the RTS members in the activities of the FDS / P2K2 is particularly evident when they are enthusiastic in receiving the material, answer the question the speaker, singing, and playing the role (role playing). It turned out that their expression is not without reason, it is very clear alasananya, because several times the implementation of the FDS / P2K2 not "steady" or a routine schedule that should be done every month.

Related to the implementation melting is occurring differences in attitudes among participants PKH when the system is turned into a non-cash disbursement is through ATM-46. Those who have been using the ATM did not make this change, but not for those who are new or have never used an ATM. But the general implementation of the disbursement goes well and smoothly.

\section{c. RTS understanding of the benefits of CCT Program}

Understanding of members of targeted households (RTS) on the benefits of family programs expectation (PKH) is "good", although there are some participants PKH still need intense intervention or approach. This happens because some of the participants PKH PKH assistance funds for personal use, but after a surveillance approach and gradually change for the better.

\subsubsection{Factors that affect the internal and external perception RTS members on the implementation and benefits of the} Family Hope Program (PKH)

\section{a. Internal factors}

Internal factors which affect members of the RTS is the education factor and motivation factor. Very strong motivational factor influence on RTS members in meeting the requirements PKH because they do not want to get sanctions in the form of cutting the amount of aid, while factors affecting education as a supporting member of the RTS on the implementation of the program and the benefits of the family hope. 


\section{b. External factors}

As for the external factors that affect members of the RTS is the social and environmental factors households background factors. Strong social environmental factors influence than family background factors, where members of the RTS in the act and behave more predominantly influenced by social environmental factors compared to the background factors households.

\section{SUGGESTION}

1. RTS members in order to use the funds in accordance with their usefulness PKH aid, and is active in all the activities that exist in the CCT program.

2. The central government and the province of East Java in order to improve access to participation for the poor who until now have not entered the CCT program.

3. Lamongan district government agencies or institutions particularly concerned to form a team together and create a program that can help the poor to no dependence on aid PKH.

\section{REFERENCES}

1. Ahmadi, Abu. 2003. Psikologi Umum. Jakarta Rineka Cipta.

2. Al-Syaibani, Omar Muhammad Al-Toumy.1979. Falsafah At-Tarbiyah Al-Islamiyah, terjemahan: Hasan Lunggalung, Jakarta: Bulan Bintang.

3. Bakry, Sidi Nazar. 1993. Kunci Keutuhan Rumah Tangga. Jakarta: Pedoman Ilmu Jaya.

4. Hermawati, Istiana. 2008. Metode dan Teknik Dalam Praktik Pekerjaan Sosial. Yogyakarta: Adicita Karya Nusa.

5. Miles, M.B, Huberman, A.M, and Saldana,J. 2014. Qualitative Data Analysis, A Methods Sourcebook, Edition 3. USA: Sage Publications. Terjemahan Tjetjep Rohindi Rohidi, UI-Press.

6. Moleong, J, Lexy. 2006. Metodologi Penelitian Kualitatif. Bandung: PT. Remaja Rosdakarya.

7. Ngalim Purwanto. 2003. Psikologi Pendidikan. Bandung: PT. Remaja Rosdakarya.

8. Poerwadarminta W.J.S. 1976. Kamus Umum Bahasa Indonesia, Jakarta: PN Balai Pustaka.

9. Walgito, Bimo. 2004. Pengantar Psikologi Umum. Yogyakarta: Andi Offset.

10. Zarkasi, Muslichah. 1986. Psikologi Manajemen. Jakarta: Erlangga. 